\title{
SISTEM PEMERINTAHAN ISLAM MENURUT AL-MAWARDI DAN APLIKASINYA DI INDONESIA.
}

\author{
Rahmawati \\ Institut Agama Islam Negeri (IAIN) Parepare \\ rahmawatitoha@stainparepare.ac.id
}

\begin{abstract}
This paper examines the system of Islamic government according to al-Mawardi and its application in Indonesia. The first study focused on the early history of government in the history of Islamic politics since the Prophet built the State of Medina until it developed until the Abbasid dynasty. Al-Mawardi, who lived in the Middle Ages when the political situation at that time was very unstable and led to the decline of the Abbasid dynasty, gave birth to a concept of a government system based on the political reality of his day. Imam alMawardi's political thinking was then poured in the work of al-Ahkam al-Sulthaniyyah and became a basic concept for the development of political thought and its application in the modern era including in Indonesia. In Indonesia, the application of al-Mawardi's theory of social contracts explains the relationship between ahl al-halli wal aqdi and ahl Imamah. This concept was then embodied and developed in the system of governance in Indonesia into 3 boards, namely: legislative institutions, executive institutions, and judicial institutions.
\end{abstract}

Keyword: System of government, social contract, ahl al-hall wal aqd, ahl Imamah

Abstrak: Tulisan ini mengkaji tentang sistem pemerintahan Islam menurut alMawardi dan aplikasinya di Indonesia. Diawali dengan kajian sejarah pemerintahan awal sejarah politik Islam sejak Nabi membangun Negara Madinah hingga mengalami perkembangan sampai pada masa dinasti Abbasiyyah. Al-Mawardi yang hidup pada abad pertengahan dimana situasi politik pada saat itu sangat tidak stabil dan mengarah pada masa kemunduran dinasti Abbasiyyah telah melahirkan sebuah konsep sistem pemerintahan yang didasarkan realitas politik pada zamannya. Pemikiran politik Imam al-Mawardi kemudian dituangkan dalam karya al-Ahkam alSulthaniyyah dan menjadi konsep dasar bagi pengembangan pemikiran politik dan penerapannya di era modern termasuk di Indonesia. Penerapannya di Indonesia tampak pada teori al-Mawardi mengenai kontrak sosial yang menjelaskan hubungan antara ahl al-halli wal aqdi dengan ahl Imamah. Konsep ini kemudian diejawantahkan dan dikembangkan dalam sistem pemerintahan di Indonesia menjadi 3 lembaga, yaitu: lembaga legislatif, lembaga eksekutif, dan lembaga yudikatif.

Kata Kunci: Sistem pemerintahan, kontrak sosial, ahl al-hall wal aqd, ahl Imamah 


\section{PENDAHULUAN}

Sistem pemerintahan dalam Islam mulai terbangun sejak Islam dibangun oleh Nabi Muhammad saw. di Madinah. Terbentuknya negara Madinah, akibat dari perkembangan penganut Islam yang menjelma menjadi kelompok sosial dan memiliki kekuatan politik riil pada pasca periode Mekkah di bawah pimpinan Nabi. Itulah sebabnya Pulungan menyebutkan bahwa negara dan pemerintahan yang pertama dalam sejarah Islam itu terkenal dengan Negara Madinah. ${ }^{1}$

D. B. Macdonald juga menyatakan bahwa di Madinahlah telah terbentuk negara Islam pertama dan telah melaksanakan dasar-dasar politik bagi perundang-undangan Islam. Dalam negara Madinah tersebut Nabi tidak hanya berfungsi sebagai Pemimpin Agama tetapi juga Kepala Negara. Fazlur Rahman juga membenarkan bahwa masyarakat Madinah yang diorganisir Nabi itu merupakan suatu negara dan pemerintahan yang membawa kepada terbentuknya umat Muslim. ${ }^{2}$ Oleh karena itu, Hitti berpendapat bahwa di atas puncak negara ini berdiri Tuhan, dan Nabi Muhammad adalah wakil Tuhan di muka bumi. Dari Madinahlah teokrasi Islam tersebar ke seluruh Arabia dan kemudian meliputi sebagian besar Asia Barat sampai Afrika Utara. ${ }^{3}$

Menurut Madjid Khadduri, apabila syariat Islam berperan dalam pemerintahan umat Islam, maka ia disebut nomokrasi. Sedangkan alMaududi menyebutkan bahwa sistem pemerintahan tersebut dinamakan teodemokrasi. ${ }^{4}$ Sebab, disamping syariat yang diwahyukan Tuhan sebagai pemegang kedaulatan tunggal mengenai berbagai ketentuan hukum, kekuasaan Tuhan berada di tangan umat untuk melaksanakan syariat. Oleh karena itu, al-Maududi membatasi kedaulatan rakyat namun umat memperoleh kedudukan utama untuk memusyawarahkan masalahmasalah yang belum jelas hukumnya dalam syariat Islam. ${ }^{5}$ 
Dengan demikian, corak sejarah Islam. $^{7}$ Sepanjang masa Negara Madinah adalah negara berasaskan syariat Islam, dan bersifat demokratis. Artinya Nabi Muhammad saw. telah menampilkan dirinya sebagai pemimpin yang melaksanakan prinsip keseimbangan antara kemaslahatan duniawi dan kemaslahatan ukhrawi bagi umatnya. ${ }^{6}$ Prinsip ini terlaksana karena Nabi menerapkan secara konsisten beberapa prinsip dalam bernegara, yaitu prinsip musyawarah, kebebasan berpendapat, kebebasan beragama, persamaan, keadilan sosial dan kesejahteraan spiritualnya, persatuan dan persaudaraan, amar ma'ruf nahi mungkar, dan prinsip ketakwaan. Sistem ini terus mengalami perubahan/perkembangan setelah masa kepemimpinan Nabi dan dilanjutkan oleh sahabat beliau yang dikenal dengan masa al-Khulafaur Rasyidin.

Pengangkatan Abu Bakar ashShiddiq menjadi khalifah pertama pada masa al-Khulafaur Rasyidin merupakan awal terbentuknya pemerintahan model khilafah dalam pemerintahan al-Khulafaur Rasyidin, para pakar politik Islam menilai bahwa sistem pemerintahan yang dijalankan sangat demokratis meskipun proses pengangkatan keempat khalifah pada masa ini memiliki cara-cara yang berbeda. ${ }^{8}$ Hal ini disebabkan karena dalam proses penyelenggaraannya dijalankan berdasarkan prinsip musyawarah, persamaan dan prinsipprinsip lainnya yang telah dicontohkan oleh Rasulullah.

Pemerintahan pasca Khulafaur Rasyidin menunjukkan perubahan yang cukup signifikan. Meskipun sistem pemerintahan tersebut dipimpin oleh seorang khalifah namun pada penyelenggaraannya menggunakan sistem dan bentuk pemerintahan monarki absolut yang sebelumnya tidak pernah terjadi. Hal ini terjadi hingga masa dinasti Abbasiyyah. Sistem dan bentuk pemerintahan monarki yang dipelopori oleh Muawiyyah bin Abi Sufyan, pendiri dinasti Umayyah, diteruskan oleh dinasti Abbasiyyah. Bahkan derajat 
seorang khalifah pada masa dinasti Abbasiyyah lebih tinggi dari gelar khalifah di zaman Dinasti Umayyah.

$$
\text { Berdasarkan sejarahnya, }
$$
tampaknya sistem pemerintahan sejak awal Islam hingga runtuhnya kerajaan bani Abbasiyyah pada abad pertengahan telah melahirkan persepsi dan konsep serta pemikiran-pemikiran baru mengenai sistem pemerintahan yang ideal dalam Islam. Banyak tokoh atau ilmuwan dalam bidang politik pemerintahan pada zaman pertengahan telah menciptakan teori-teori yang dapat diaplikasikan dalam sebuah negara. Disebutkan Suyuthi Pulungan bahwa pemikiran politik Islam dalam bentuk rumusan yang sistematis belum tampak hingga periode Dinasti Abbasiyyah. ${ }^{9}$ Di antara tokoh-tokoh terkemuka dalam sejarah Islam yang hidup pada masa klasik dan abad tengah adalah al-Baqillani, alBaghdadi, Ibn Abi Rabi', al-Farabi, alMawardi, al-Juwaini, al-Gazzali, Ibnu Taymiyyah, dan Ibnu Khaldun.

Oleh karena banyaknya tokoh yang telah memberikan kontribusi pemikiran politik Islam, maka tulisan ini akan difokuskan pada pemikiran Imam al-Mawardi mengenai sistem pemerintahan Islam dan bagaimana aplikasinya di Indonesia.

Pentingnya kajian ini disebabkan selain karena Imam alMawardi cukup banyak meninggalkan karya-karya yang berkaitan dengan politik juga karena pemikirannya dalam bidang ini cukup realistis karena teori politik yang dikemukakan berbasis pada realitas sosial politik dan pengalamannya sebagai salah seorang pejabat pemerintahan pada zamannya.

\section{PEMBAHASAN}

1. Sketsa Biografi Imam al-Mawardi Imam al-Mawardi adalah seorang ahli fikih, ahli hadis, dan politikus muslim (pemikir politik Islam). Nama lengkapnya adalah Abu Hasan Ali bin Muhammad bin Habib al-Mawardi. Ia dikenal sebagai tokoh terkemuka Mazhab Syafi'I pada abad ke-10 dan pejabat tinggi yang berpengaruh besar dalam pemerintahan Abbasiyyah. Dia juga seorang fakih Mazhab Syafi'I yang menaruh 
perhatian penuh terhadap pembahasan tentang Imamah atau khilafah (konsep negara dan pemerintahan Islam), sebagai suatu system politik. Ia mempertahankan system politik Islam di tengah semakin menurunnya supremasi politik Dinasti Abbasiyah. Sebelumnya, sejak abad ke-8 hingga ke-10, Dinasti Abbasiyyah memiliki supremasi politik yang tinggi.

Al-Mawardi belajar fikih dari seorang ulama terkenal di Basra, yaitu Syeikh ash-Shaimiri dan Syekh Abu Hamid (keduanya ahli hukum Islam). Sejak kecil, ia senang sekali mendalami fikih, khususnya yang berkaitan dengan fikih siyasi (tata negara dan pemerintahan Islam). Setelah dewasa, ia menjadi hakim (kadi) yang terkenal (karena sering berpindah-pindah) pada masa pemerintahan khalifah Abbasiyyah, alQadir (berkuasa 381 H/991 M- 423 H/1031M). Karir al-Mawardi meningkat setelah ia menetap kembali di Baghdad, yaitu menjadi hakim agung (Qadi al-Qudat), penasihat raja atau khalifah di bidang agama (hukum Islam) dan pemerintahan.

Karyanya dalam bidang politik Islam yang sangat menonjol antara lain: (1) al-Ahkam al-Sulthaniyyah (Peraturan-peraturan

Kerajaan/Pemerintahan); (2) Qawanin al-Wuzarah (Ketentuan-ketentuan Kewaziran/kementerian), (3) Siyasah al-Muluk (Strategi Kepemimpinan Raja/pemimpin). (4) Adab ad-Dunya wa ad-Din (tata Krama Kehidupan Politik/Duniawi dan Agamawi); (5) alHawi (Yang Terhimpun); dan (6) alIqna' (keikhlasan). ${ }^{10}$

Dari keenam karya di atas, Munawir Sadzali mencatat bahwa hanya dua di antaranya yang telah dicetak, yaitu: al-Ahkam alSulthaniyyah (Peraturan-peraturan Kerajaan/Pemerintahan), dan Qawanin al-Wuzarah, Siyasah al-Malik (Ketentuan-ketentuan Kewaziran, Politik Raja). ${ }^{11}$

2. Pemikiran Imam al-Mawardi tentang Sistem Pemerintahan Islam

Pemikiran al-Mawardi tentang sistem pemerintahan Islam dapat 
ditelaah dari beberapa karya tulisnya dalam bidang politik. Karyanya, alAhkam al-Sulthaniyah merupakan karya monumental yang cukup lengkap memuat pokok-pokok kenegaraan dan kepemerintahan seperti jabatan khalifah, syarat-syarat agar dapat diangkat sebagai khalifah, pengangkatan para pembantunya (baik pada pemerintahan pusat maupun daerah), dan perangkat lain pemerintahan serta fungsi dan tugasnya.

Menurut Fathiyah anNabrawiyah (pemikir politik dari Mesir), pemikiran politik al-Mawardi berangkat dari kerangka teori politik yang berdasarkan pada prinsip hukum Islam. Artinya, pendekatan fikih merupakan titik tolak teori politik alMawardi. ${ }^{12}$

Al-Mawardi berijtihad dan menyusun sebuah kerangka politik tentang apa yang harus dilakukan dalam suatu pemerintah, seperti ketentuan pokok dalam pengangkatan seorang khalifah, tugas-tugas khalifah dan pejabat negara, dan hubungan negara dengan rakyat.

Berikut pokok-pokok pemikiran politik dan kepemerintahan Islam dalam pandangan al-Mawardi:

1. Konsep Sebuah Kenegaraan Dalam pandangan al-Mawardi, dari segi politik negara diperlukan enam sendi utama sebagai berikut:

a. agama yang dianut dan dihayati sebagai kekuatan moral. Agama dapat mengendalikan keinginan dan hawa nafsu manusia. Karena menjadi pengawas melekat pada hati nurani manusia, maka agama merupakan sendi yang paling pokok bagi kesejahteraan dan stabilitas Negara.

b. penguasa yang kharismatik, berwibawa dan dijadikan teladan. Dengan memiliki sifatsifat itu, seorang penguasa dapat mempersatukan aspirasiaspirasi yang berbeda-beda (heterogen); membina Negara untuk mencapai tujuan luhur; menjaga agar agama dihayati 
serta diamalkan; dan melindungi rakyat, kekayaan, serta kehormatan mereka.

Dalam konteks ini, penguasa adalah imam atau khalifah.

c. keadilan yang menyeluruh. Sebagai tujuan luhur dan paling esensial, keadilan berkait erat dengan syarat untuk menjadi penguasa, yaitu seorang yang adil. Keadilan bagi masyarakat adalah cermin sebuah Negara makmur dan bermoral.

d. keamanan yang merata. Situasi aman sangat tergantung pada keadilan. Dengan meratanya keamanan, rakyat hidup tenang dan dapat melaksanakan kewajiban dan haknya sebagai rakyat.

e. kesuburan bumi (tanah). Bumi yang subur menjamin kebutuhan rakyat akan bahan pangan, pakaian dan kebuthan materi lainnya. Oleh karena itu, bumi harus diolah dan dimanfaatkan secara maksimal. f. Harapan kelangsungan hidup. Dalam kehidupan manusia terdapat kaitan yang erat anatara generasi dengan generasi yang lain. Generasi yang sekarang adalah pewaris dari generasi yang lalu, dan yang mempersiapkan saransarana dan wahana-wahana hidup bagi generasi yang datang. Nabi Muhammad bersabda, "Adanya harapan adalah satu rahmat dari Allah kepada umatku. Kalau misalnya tidak ada harapan orang tidak akan (payah-payah) menanam pohon, dan seorang ibu tidak akan menyusui anaknya."

\section{Sistem Pemerintahan}

Sistem pemerintahan dalam pandangan al-Mawardi mendasarkan teori politiknya atas dasar kenyataan yang ada dan kemudian secara realistik menawarkan saran-saran perbaikan atau reformasi, misalnya dengan mempertahankan status quo. Oleh karena itu, sistem pemerintahannya 
seperti konsep mengenai kepemimpinan dan cara-cara pemilihannya sangat dipengaruhi oleh konteks politik yang berkembang pada masa hidup al-Mawardi.

a. Konsep Imamah (Kepemimpinan)

Yang dimaksud oleh alMawardi dengan imamah adalah khalifah, raja, sultan atau kepala Negara. Menurutnya, imamah adalah jabatan politis keagamaan. Imam adalah pengganti (khalifah) Nabi Saw. yang bertugas menegakkan agama dan mengatur politik umat Islam ${ }^{13}$. Dengan demikian, seorang imam di satu pihak adalah pemimpin agama dan di pihak lain sebagai pemimpin politik. Hukum untuk mendirikannya adalah wajib menurut syarak atas dasar ijmak umat. Pandangannya ini didasarkan pada beberapa ayat al-Qur'an, di antaranya QS. An-Nisa/4: 59.

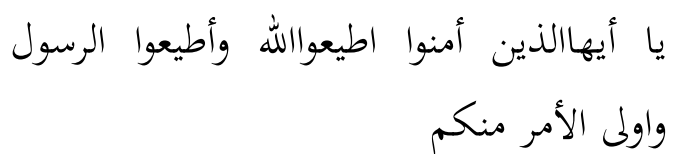

Terjemahnya:

"Wahai orang-orang yang beriman, taatilah Allah dan taatilah Rasul (Muhammad), dan ulil amri (pemegang kekuasaan) di antara kamu..."14

Sedangkan dasar-dasar atau pokok-pokok imamah, al-Mawardi juga merujuk pada al-Qur'an dan asSunnah an-Nabawiyyah, yaitu majelis Syura (pemufakatan) dan baiat (persetujuan dan pengakuan umat). Sebagai realisasinya telah dilakukan pemilihan atas pengangkatan Abu Bakar sebagai khalifah atas dasar pemufakatan (syura) para pemuka Ansar dan Muhajirin dalam sidang yang berlangsung di Saqifah (bangsal) Bani Sa'idah di Madinah. Pengangkatan itu kemudian mendapat persetujuan dan pengakuan umat (baiat). Tradisi ini tetap berlaku pada pengangkatan dan pemilihan khalifahkhalifah berikutnya.

b. Mekanisme Pemilihan dan Pengangkatan Imam

Menurut Mawardi, cara pemilihan pemimpin menggunakan dua pola, yaitu pemilhan yang dilakukan oleh ahl al-hall wa al-aqd dan penunjukan atau wasiat dari imam, khalifah atau raja sebelumnya. Dalam konteks ini, Imam al-Mawardi 
mengemukakan bahwa diperlukan dua hal:

1) Ahl al-Ikhtiar (para pemilih). Menurutnya, tidak semua orang berhak melakukan pemilihan atas imam. Imam hanya dipilih oleh wakil-wakil rakyat dengan memiliki syarat-syarat tertentu, seperti bersifat adil, mengetahui syarat-syarat khalifah, dan memiliki kesanggupan untuk menentukan dengan bijaksana siapa yang berhak menjadi khalifah dari calon-calon yang ada. Wakil-wakil rakyat ini disebut ahl al-hall wa al-aqd (orang-orang yang mempunyai wewenang untuk memecahkan masalah dan menetapkan keputusan). Begitu pentingnya kewenangan ahl al-hall wa alaqd, maka Imam al-Mawardi menetapkan beberapa syarat menjadi ahl al-Ikhtiar, yaitu: (1) memiliki sikap adil; (2) memiliki ilmu pengetahuan yang mampu mengetahui siapa yang memenuhi syarat untuk diangkat sebagai imam; dan (3) memiliki wawasan yang luas dan kearifan dalam memilih siapa yang paling tepat untuk menjadi imam dan mampu mengelola kepentingan umat di antara mereka yang memenuhi syarat untuk jabatan itu. ${ }^{15}$

2) Ahl al-Imamah (yang berhak dipilih). Imam atau khalifah harus memenuhi tujuh kriteria; (1) memiliki sifat adil dengan segala persyaratannya, memiliki ilmu pengetahuan yang memadai untuk berijtihad dalam masalah hukum dan pengelolaannya, (3) sehat mental, (4) sehat fisik, (5) berwawasan luas untuk mengatur kehidupan dan kepentingan umat, (6) memiliki keberanian dan ketegasan untuk melindungi rakyat dan menumpas musuh, dan (7) keturunan Kuraisy, ${ }^{16}$ karena telah ditetapkan oleh nas dan ijmak sebagaimana disabdakan, 
"al-A'immah min Quraisy", yang artinya: "Para pemimpin adalah harus dari keturunan Kuraisy" (HR. al-Bukhari dan Muslim).

Dengan adanya pemilihan dan persyaratan yang cukup ketat dalam pengangkatan calon imam maka tentu berkonsekwensi pada kemungkinan adanya pemakzulan atau pemecatan seorang Imam jika sudah menyimpang dari kriteria dari seorang pemimpin. Di sinilah pentingnya adanya perjanjian Imam dengan umat sebagai komitmen untuk menjalankan kewajibannya dengan tulus dan ikhlas. Bagi umat, perjanjian itu mengandung arti bahwa mereka akan mematuhi dan mendukung khalifah atau Imam. Jika kepatuhan umat itu hilang yang disebabkan imam melanggar perjanjiannya dengan umat maka kekhalifahannya juga akan hilang hingga terjadi pemakzulan/pemecatan Imam. Menurut Imam al-Mawardi, kehilangan kekhalifahan dapat terjadi apabila (1) khalifah atau imam kehilangan sifat adil, memperturutkan hawa nafsu, dan melakukan kemungkaran; (2) khalifah atau imam kehilangan kesehatan mental atau fisik (misalnya kehilanga akal, penglihatan, rasa, dan penciuman); ${ }^{17}$ (3) khalifah atau imam menjadi tawanan atau kekuasaannya dirampas oleh sultan atau amir yang mengakibatkan kemerdekaannya hilang. $^{18}$ Konsep dasar dari Imam al-Mawardi inilah yang menjadi cikal bakal lahirnya teori kontrak sosial.

c. Teori Kontrak Sosial

Dengan adanya gagasan ketatanegaraan al-Mawardi mengenai perjanjian atau kontrak sosial semakin memperjelas pentingnya hubungan antara ahl al-aqdi wa al-Halli atau ahl al-Ikhtiar dan imam atau kepala Negara. Hubungan ini merupakan hubungan antara dua pihak peserta kontrak sosial atau perjanjian atas dasar sukarela, satu kontrak atau persetujuan yang melahirkan kewajiban dan hak bagi kedua belah pihak atas dasar timbal balik. Oleh karenanya, selain berhak untuk ditaati oleh rakyatnya dan menuntut loyalitas 
penuh dari mereka, imam juga mempunyai kewajiban-kewajiban yang harus dipenuhi terhadap rakyatnya, seperti memberikan perlindungan kepada mereka dan mengelola kepentingan mereka dengan baik dan penuh tanggung jawab.

Menurut al-Mawardi, antara lain yang menjadi kewajiban seorang imam adalah: (a) menjaga dasar-dasar agama yang telah disepakati ulama salaf, (b) menegakkan keadilan, supaya yang kuat tidak menganiaya yang lemah dan yang lemah tidak merasa teraniaya, (c) menegakkan hukum, supaya agama Allah SWT dan hak-hak umat terjaga, (d) menjaga keamanan dan menjaga daerah kekuasaannya dari gangguan musuh dan penjahat, sehingga umat dapat menjalankan kehidupan mereka dengan baik dan jiwa dan harta mereka terjamin, (e) mengadakan jihad atau memerangi orang-orang yang memusuhi Islam, sehingga mereka menganut Islam atau mengikat perjanjian damai supaya semua orang bebas menganut dan menjalankan
Allah swt. (f) mengatur pengelolaan keuangan negara. ${ }^{19}$ Sedangkan hakhak imam diperoleh apabila imam telah menjalankan kewajibannya dan memberikan hak rakyat serta menunaikan hak Allah swt, maka rakyat berkewajiban mematuhi dan mendukung kebijaksanaannya. ${ }^{20}$

Pemikiran al-Mawardi yang telah memperkenalkan teori kontrak sosial pada awal abad XI Masehi telah menginspirasi pemikir politik selanjutnya terutama pada perkembangan pemikiran politik di Eropa. Keunikan dari pemikiran ini sangat menarik karena teori ini diperkenalkan jauh sebelumnya pada awal abad XI Masehi dan baru bermunculan setelah lima abad kemudian, yakni pada pertengahan abad XVI Masehi bermunculan teori kontrak sosial di Barat. Menurut Munawir Sadzali, sedikitnya terdapat empat pemikir politik Barat yang mengemukakan teori kontrak sosial, dengan versi yang berbeda satu sama llainnya, Yaitu; Hubert Languet (1519$1581 \mathrm{M}),{ }^{21}$ Thomas Hobbes (1588- 
$1679 \mathrm{M})^{22}$, John Locke (1632-1704 M) ${ }^{23}$ dan Jean Jaques Rousseu (1712$1778 \mathrm{M}){ }^{24}$

Selain keunikan di atas alMawardi juga satu-satunya dari enam pemikir politik Islam sampai Zaman Pertengahan yang berpendapat bahwa kepala Negara dapat diganti kalau ternyata tidak mampu lagi melaksanakan tugasnya, baik disebabkan oleh soal moral maupun soal-soal lain sekalipun al-Mawardi tidak memberikan cara atau mekanisme bagi penggantian kepala Negara itu. Juga tidak menjelaskan bagaimana ahl al-Ikhtiar atau Ahl alAqdi wa al-Halli itu diangkat, dan dari kalangan mana dan berdasarkan kualifikasi pribadi atau perwakilan kelompok.

3. Aplikasi Pemikiran Politik Imam alMawardi di Indonesia

Imam al-Mawardi membangun teori politiknya berdasarkan realitas politik pada zamannya. Sebagaimana yang dikemukakan Munawir Sadzali, situasi politik di dunia Islam pada masa al-Mawardi, yakni sejak menjelang akhir abad $\mathrm{X}$ sampai pertengahan abad XI M, tidak lebih baik daripada masa Farabi. ${ }^{25}$ Semula Baghdad merupakan pusat peradaban Islam dan poros negara Islam. Khalifah di Baghdad merupakan otak peradaban itu, dan sekaligus jantung Negara dengan kekuasaan dan wibawa yang menjangkau semua penjuru dunia Islam. Tetapi kemudian lambat laun cahaya yang gemerlapan itu pindah dari Baghdad ke kota-kota lain. Kedudukan khalifah mulai melemah, dan dia harus membagi kekuasaannya dengan panglima-panglimanya yang berkebangsaan Turki atau Persia. Mulai tampak bahwa tidak mungkin lagi imperium Islam yang demikian luas wilayahnya harus tunduk kepada seorang kepala negara tunggal. Pada waktu itu khalifah di Baghdad hanya merupakan kepala negara yang resmi dengan kekuasaan formal saja, sedangkan yang mempunyai kekuasaan sebenarnya dan pelaksana pemerintahan adalah pejabat-pejabat tinggi dan panglima-panglima yang berkebangsaan Turki atau Persia serta 
penguasa-penguasa wilayah. Meskipun makin lama kekuasaan para pejabat tinggi dan panglima non Arab itu makin meningkat, sampai waktu itu belum tampak adanya usaha di pihak mereka untuk mengganti khalifah Arab itu dengan khalifah yang berkebangsaan Turki atau Persia. Namun dalam kondisi seperti ini mulai terdengar tuntutan dari sementara golongan agar jabatan itu dapat diisi oleh orang bukan Arab dan tidak dari suku Quraisy. Tuntutan itu tentu menimbulkan reaksi dari golongan lain, khususnya dari golongan Arab, yang ingin mempertahankan syarat keturunan Quraisy untuk mengisi jabatan kepala negara, serta syarat kebangsaan Arab dan beragama Islam untuk mengisi untuk menjabat wazir tafwidh atau penasehat dan pembantu utama khalifah dalam menyusun kebijaksanaan. Dalam kondisi yang kacau maka menurut al-Mawardi status quo perlu dipertahankan agar stabilitas keamanan dan politik tetap terjaga. Itulah sebabnya, Imam al-
Mawardi mensyaratkan pemimpin itu harus dari keturunan Arab.

$$
\text { Meskipun terkesan }
$$

diskriminatif, pandangan Imam alMawardi tersebut mengandung upaya preventif terjadinya pemberontakan pada masanya dimana situasi dan kondisi politik saat itu tidak stabil. Dan konteks keindonesiaan, aturan yang sama juga tampak dalam konstitusi negara. Dalam sistem ketatanegaraan sebagaimana dalam UUD 1945 jelas hanya mempersyaratkan warga negara Indonesia sebagai kepala negara/presiden. Dalam pasal 6 ayat 1 UUD 1945 menyebutkan, "Presiden ialah orang Indonesia asli”. ${ }^{26}$

Aturan ini jelas menutup kesempatan bagi keturunan warga negara lain menjadi kepala negara. Apa yang dikemukakan al-Mawardi maupun yang tercantum dalam konstitusi negara di Indonesia sangat politis dan bersifat lokal sehingga dapat saja diamandemen sesuai zamannya. Oleh karena itu, dibutuhkan upaya kontekstualisasi dari hadis Nabi 
yang dijadikan dasar oleh Imam alMawardi dalam menetapkan persyaratan ahl imam harus dari keturunan Kuraisy".

Dasar atau pokok Imamah yang dikemukakan al-Mawardi tetap bersumber dari al-Qur'an, yakni prinsip syura (kesepakatan) ${ }^{27}$ dan baiat (persetujuan dan pengakuan umat). Oleh karena itu, persyaratan ahl imamah sangat kondisional sesuai kesepakatan dan persetujuan umat.

Dalam UU Pilpres, pasal 5 sangat konkret menjelaskan persyaratan calon presiden dan wakil presiden. ${ }^{28}$ Meskipun beberapa persyaratan tersebut memiliki persamaan secara substansial dengan pandangan al-Mawardi akan tetapi persyaratan dalam undang-undang ini lebih terbuka dalam memberikan hak setiap warga negara sekalipun tidak sehat atau cacat secara jasmani. Penetapan KH. Abdurrahman Wahid (Gusdur) sebagai presiden keempat di Indonesia merupakan salah satu contoh kesepakatan berdasarkan prinsip syura dalam menetapkan kepala negara sekalipun ahl imamah itu memiliki kekurangan secara jasmani.

Demikian pula pandangan alMawardi tentang sistem pemilihan kepala negara juga tampak penerapannya di Indonesia meskipun pada proses pelaksanaannya memperlihatkan pengembangan yang bersifat teknis. Misalnya teori kontrak sosial, Imam al-Mawardi sangat sederhana menjelaskan hubungan antara ahl al-Aqdi wa al-Halli atau ahl al-Ikhtiar dan imam atau kepala negara sebagai dua pihak peserta kontrak sosial atau perjanjian namun pada penerapannya di Indonesia, lembaga ini sama dengan lembaga DPR/MPR.

Farid Abdul Khaliq menyebutkan bahwa sebutan kelompok ahl al-Aqd wa al-Halli dalam turats fikih kita sejak awal Islam adalah "Dewan Perwakilan Rakyat" atau ahlul Ikhtiyar, dimana terdiri dari para ulama, para pemimpin suku dan pemuka masyarakat. Kelompok ini memiliki kewenangan atau berhak untuk memilih atau menobatkan dan memberhentikan khalifah. ${ }^{29}$ Imam al- 
Mawardi menyatakan apabila ahlul Halli wa al-Aqd berkumpul untuk memilih, meneliti keadaan orangorang yang berhak menjadi pemimpin apakah sesuai kriteria kemudian diajukan orang terbaik dan senpurna untuk disumpah maka rakyatpun harus taat kepadanya dan tidak menahan diri dari membaiatnya. ${ }^{30}$

Dalam konstitusi negara di Indonesia kewenangan lembaga MPR/DPR memiliki persamaan dengan yang dikemukakan oleh Imam al-Mawardi, yaitu kewenangan untuk memilih kepala negara. Hanya saja mekanisme pemilihan tersebut tetap menggunakan prinsip syura melalui suara terbanyak. Dalam UUD 1945 pasal 6 ayat 2 disebutkan :

"Presiden dan Wakil Presiden dipilih oleh Madjelis Permusjawaratan rakyat dengan suara yang terbanyak". 31

Kewenangan ini telah berubah sejak masa reformasi pada tahun 1998, dimana kedaulatan penuh ada di tangan rakyat. Bahwa dalam memilih presiden dan wakil presiden dilakukan secara langsung oleh rakyat dengan suara terbanyak. Dengan demikian, kewenangan lembaga negara seperti MPR/DPR hanya mengukuhkan atau melantik presiden dan wakil presiden terpilih. Selain itu, lembaga ini memiliki fungsi legislatif, yakni berfungsi membuat Undang-undang. Dalam Amandemen UUD 1945 pasal 20 menyebutkan:

"Dewan Perwakilan Rakyat memegang kekuasaan membentuk undang-undang. Dan pasal 20A : Dewan Perwakilian Rakyat memiliki fungsi legislasi, fungsi anggaran, dan fungsi pengawasan."32

Dalam UUD 1945 amandemen pada pasal 9 menyebutkan bahwa sebelum memangku jabatannya, presiden dan wakil presiden mengadakan sumpah jabatan di hadapan MPR/DPR sebagai bentuk kontrak sosial. ${ }^{33}$

Dengan demikian, pemikiran Imam al-Mawardi tampaknya dapat ditemukan konsep dasarnya dalam konstitusi pemerintahan negara 
Indonesia. UUD 1945 sebagai basic law mengandung unsur-unsur tertentu yang pada dasarnya sudah dikembangkan Imam al-Mawardi pada abad pertengahan. Hanya saja hukum konstitusi ini telah mengalami beberapa perubahan seiring perkembangan zaman. Oleh karena itu, konsep dasar dari pemikiran Imam alMawardi telah mengalami perkembangan seperti teori kontrak sosial serta fungsi dan kewenangan lembaga-lembaga kenegaraan. Kontrak sosial yang hanya melibatkan antara ahlul ahli wal aqdi dan ahl Imam kini dikembangkan dalam konstitusi negara kita dengan membatasi dan menetapkan fungsi-fungsi dan kewenangan lembaga kepemerintahan menjadi tiga, yaitu: lembaga legislatif, lembaga eksekutif, dan lembaga yudikatif.

Lembaga legislatif merupakan pengejawantahan dari ahlul ahli wal aqdi yang berfungsi sebagai lembaga yang mempunyai dan menjalankan kekuasaan membuat peraturan perundang-undangan. ${ }^{34}$ Lembaga eksekutif merupakan pengejawantahan dari ahl Imamah yang berwenang menjalankan roda pemerintahan. Lembaga yudikatif merupakan pengembangan konsep-konsep ketatanegaraan yang berfungsi untuk membela hukum-hukum positif dari setiap serangan dan pelanggaran.

\section{PENUTUP}

Berdasarkan pembahasan sebelumnya, dapat disimpulkan; Pertama, pemikiran Imam al-Mawardi tentang sistem pemerintahan Islam sangat realistis dan demokratis. Hal ini disebabkan karena Imam al-Mawardi membangun kerangka konseptual mengenai penyelenggaraan ketatanegaraan yang ideal berdasarkan permasalahan politik yang muncul pada realitas zamannya. Selain itu, ia juga telah mengembangkan konsep baru tentang ahl imamah, ahlul halli wal aqdi dan hubungan keduanya melalui kontrak sosial dan berdampak pada kehidupan politik yang lebih demokratis. Kedua, penerapan konsep dan pemikiran al-Mawardi tentang sistem pemerintahan Islam di 
Indonesia sangat memberikan pengaruh yang sangat besar dalam mewujudkan kehidupan berdemokrasi yang lebih adil, adanya pemisahan fungsi lembaga pemerintahan dalam teori trias politika: antara lembaga legislatif, eksekutif dan yudikatif pada dasarnya merupakan pengembangan dari teori kontrak sosial yang dibangun Imam al-Mawardi. Dengan demikian, pemikiran al-Mawardi dapat diterapkan di Indonesia.

\section{Daftar Pustaka}

\section{Bibliography}

Kementerian Agama, Al-Qur'an dan Terjemah Dilengkapi dengan Kajian Usul Fiqih. Cet. 1; Bandung: Sygma, 2011.

al-Maududi, Abul A'la, Hukum dan Konstitusi Sistem Politik Islam, Terj. Drs. Asep Hikmat, The Islamic Law and Constitution. Cet. 4; Bandung: Mizan, 1995

al-Mawardi, Imam, al-Ahkam alSulthaniyyah. Cet. 1; Tnt: Dar al-Fikr, 1960.

al-Qardhawi, Dr. Yusuf, Fiqih Daulah dalam Perspektif al-Qur'an dan Sunnah, terj. Kathur Suhardi, Min Fiqh ad-Daulah Fil Islam. Cet. 1; Jakarta: Pustaka Al-Kautsar, 1997.

Amandemen UUD 1945, Pdf amandemen uud 1945 disdik.kaltimprov.go.id/ read/getfile/3. Diakses Tanggal 16 Juli 2015

al-Syawi, Taufiq Muhammad, Dr. Syura; Bukan Demokrasi, terj. Djamaluddin Z. S, Fiqh asySyura wa al-Istisyarat. Cet. 1; Jakarta: Gema Insani Press, 1997.

Dahlan, Abdul Asiz, dkk. Ensiklopedi Hukum Islam. 6 Jilid, Cet. 1; Jakarta: Ichtiar Baru van Hoeve, 1996.

Hitti, Philip K. History of the Arabs, terj. R. Cecep Lukman Yasin, 
dkk., History of the Arabs; From the Earliest Times to the Present. Jakarta: PT Serambi Ilmu Semesta, 2006.

http://www.rumahpemilu.com/public/d oc/2014_10_27_06

42_44_UU_23_tahun_2014.pdf

. Diakses Tanggal 15 Juli 2015

Khaliq, Farid Abdul, Fikih Politik Islam, terj. Fathurrahman A Hamid, Lc. Fi al-Fiqh al-Siyasi al-Islami Mabadi Dusturiyyah asy-Syura al-adl al-Musawah Jakarta: Amzah, 2005.

Nasution, Harun, Islam Ditinjau dari Berbagai Aspek, jilid 1. Jakarta: UIP, 2001.

Pulungan, J. Suyuthi, Dr. Fiqh Siyasah: Ajaran, Sejarah, dan Pemikiran. Cet. 2; Jakarta: PT RajaGrafindo Persada, 1995.

Rusdi, Muhammad Ali. "Maslahat sebagai Metode Ijtihad dan Tujuan Utama Hukum Islam." DIKTUM: Jurnal Syariah dan Hukum 15.2 (2017): 151-168.

Salim, Abd. Muin, Dr. Fiqh Siyasah; Konsepsi Kekuasaan Politik dalam al-Qur'an. Cet. 2; Jakarta: Rajawali Pers, 1995.

Sjadzali, H. Munawir MA., Islam dan Tata Negara: Ajaran, Sejarah, dan Pemikiran. Jakarta: Universitas Indonesia (UI) Press, 1993.

\section{Catatan Akhir}

${ }^{1}$ J. Suyuthi Pulungan, Fiqh Siyasah: Ajaran, Sejarah, dan Pemikiran (Cet. 2; Jakarta: PT RajaGrafindo Persada, 1995), h. 77

2 J. Suyuthi Pulungan, Fiqh Siyasah: Ajaran, Sejarah, dan Pemikiran, h. 78

${ }^{3}$ Philip K. Hitti, History of the Arabs, terj. R. Cecep Lukman Yasin, dkk., History of the Arabs; From the Earliest Times to the Present (Jakarta: PT Serambi Ilmu Semesta, 2006), h. 151.

${ }^{4}$ Yang dimaksud dengan konsep ini bahwa komposisi dan struktur sebuah negara Islam adalah kedaulatan tertinggi ada di tangan Tuhan. Islam menggunakan kekhalifahan karena dalam Islam kedaulatan hanya milik Tuhan saja. Siapapun yang memerintah sesuai hukum Tuhan pastilah merupakan khalifah dari penguasa tertinggi dan tidak akan berwenang mengerahkan kekuasaan apapun terkecuali kekuasaan-kekuasaan yang didelegasikan kepadanya. Lebih jauh lihat Abul A'la al-Maududi, Hukum dan Konstitusi Sistem Politik Islam, Terj. Asep Hikmat, The Islamic Law and Constitution (Cet. 4; Bandung: Mizan, 1995), h. 168-172

${ }^{5}$ Abul A'la al-Maududi, Hukum dan Konstitusi Sistem Politik Islam, h.171.

${ }^{6}$ Muhammad Ali Rusdi, "Maslahat sebagai Metode Ijtihad dan Tujuan Utama Hukum Islam." DIKTUM: Jurnal Syariah dan Hukum 15.2 (2017): 151-168.

${ }^{7}$ Disebut sistem khilafah karena model pemerintahan dipimpin oleh seorang khalifah yang berarti pengganti kenabian dalam memelihara urusan agama dan mengatur urusan dunia untuk meneruskan pemerintahan Negara Madinah yang terbentuk pada masa Nabi. Yusuf al-Qardhawi memknai khilafah adalah perwakilan atas nama Rasulullah saw. untuk menjaga agama dan mengatur kehidupan dunia. Dr. Yusuf alQrdhawi, Fiqih Daulah dalam Perspektif alQur'an dan Sunnah, terj. Kathur Suhardi, Min Fiqh ad-Daulah Fil Islam (Cet. 1; Jakarta: Pustaka Al-Kautsar, 1997), h. 49. 
${ }^{8}$ Para sejarahwan menyimpulkan
bahwa pengangkatan empat sahabat Nabi
terkemuka itu menjadi khalifah dipilih dan
diangkat dengan cara yang berbeda, yaitu; (1)
pemilihan bebas dan terbuka melalui forum
musyawarah tanpa ada seorang calon
sebelumnya. Cara ini tampak pada musyawarah terpilihnya Abu Bakar dibalai pertemuan Tsaqifah Bani Saidah (2) pemilihan dengan cara pencalonan atau penunjukkan oleh khalifah sebelumnya dengan terlebih dahulu mengadakan konsultasi dengan para sahabat terkemuka dan kemudian diberitahukan kepada umat Islam dan merek menyetujuinya. Cara ini dilakukan pada penunjukkan Umar bin Khattab oleh Abu Bakar. (3) pemilihan team atau majelis syura' yang dibentuk khalifah. Anggota team bertugas memilih salah seorang dari mereka menjadi khalifah. Cara ini terjadi pada pengangkatan Usman melalui majelis Syura yang dibentuk oleh khalifah Umar yang beranggotakan enam orang. (4) pengangkatan spontanitas di tengah-tengah situasi yang kacau akibat pemberontakan sekelompok masyarakat muslim yang membunuh Usman. Cara ini terjadi pada Ali yang dipilih oleh kaum pemberontak dan umat Islam Madinah. Dr. J. Suyuthi Pulungan, Fiqh Siyasah: Ajaran, Sejarah, dan Pemikiran, h. 160. Harun Nasution, Islam Ditinjau dari Berbagai Aspek, jilid 1 (Jakarta: UIP, 2001),h.88-101.

${ }^{9}$ J. Suyuthi Pulungan, Fiqh Siyasah: Ajaran, Sejarah, dan Pemikiran,h. 213

${ }^{10}$ Lihat Abdul Asiz Dahlan, Ensiklopedi Hukum Islam (Cet. 1; Jakarta: Ichtiar Baru van Hoeve, 1996), h. 368 dan 1164.

${ }^{11}$ H. Munawir Sjadzali, MA., Islam dan Tata Negara: Ajaran, Sejarah, dan Pemikiran (Jakarta: Universitas Indonesia (UI) Press, 1993), h. 59.

${ }^{12}$ Abdul Asiz Dahlan, Ensiklopedi Hukum Islam (cet. 1; Jakarta: Ichtiar Baru Van Hoeve, 1996), h. 1162.

${ }^{13}$ Imam al-Mawardi, al-Ahkam alSulthaniyyah (Cet. 1; Tnt: Dar al-Fikr, 1960), h.5
${ }^{14}$ Kementerian Agama, Al-Qur'an dan Terjemah Dilengkapi dengan Kajian Usul Fiqih (Cet. 1; Bandung: Sygma, 2011), h. 87

${ }^{15}$ Imam al-Mawardi, al-Ahkam alSulthaniyyah, h. 6.

${ }^{16}$ Imam al-Mawardi, al-Ahkam alSulthaniyyah, h. 6

${ }^{17}$ Imam al-Mawardi, al-Ahkam alSulthaniyyah, h. 17

${ }^{18}$ Imam al-Mawardi, al-Ahkam alSulthaniyyah, h. 20

${ }^{19}$ Imam al-Mawardi, al-Ahkam alSulthaniyyah, h. 15-16.

${ }^{20}$ Imam al-Mawardi, al-Ahkam alSulthaniyyah, h. 17.

${ }^{21}$ Languet dalam bukunya yang berjudul Vindiciae Contra Tyrannus (suatu pembelaan kebebasan terhadap tiran-tiran) yang diterbitkan dalam bahasa Latin tahun 1579 dan disalin dalam bahasa Perancis tahun 1581, Languet dengan nama samaran Stephen Junius Brutus mengajukan teori kontraknya dengan mengatakan, bahwa pembentukan negara itu didasarkan atas dua kontrak: yang pertama : dibuat antara Tuhan di satu pihak dan raja serta rakyat di pihak lain, yang berisikan janji bahwa raja dan rakyat akan tetap patuh kepada perintah-perintah agama sebagai hamba-hamba Tuhan; yang kedua, dibuat antara raja dan rakyat yang berisikan bahwa rakyat berjanji untuk taat dan patuh kepada raja asalkan raja memerintah dengan adil. H. Munawir Sjadzali, Islam dan Tata Negara: Ajaran, Sejarah dan Pemikiran (Jakarta: Universitas Indonesia Press, 1993), h. 67

${ }^{22}$ Hobbes dalam bukunya, Leviathan mengemukakan bahwa dalam kehidupan alamiah (state of nature) yang memiliki kebebasan penuh dan kepentingan yang berbeda bahkan bertentangan. Oleh karena dibutuhkan kontrak sosial dalam bernegara. Berbeda dengan yang lainnya, menurut Hobbes, kontrak sosial itu terjalin antara sesame rakyat sendiri, dan raja tidak merupakan pihak dari kontrak atau perjanjian tersebut, tetapi prodik darinya. Oleh karena itu, raja tidak terikat oleh kewajiban-kewajiban terhadap kontraktor. Raja dengan kekuasaan 
mutlak merupakan pelimpahan dari kekuasaan orang-seorang anggota masyarakat yang ikut membuat kontrak sosial itu. H. Munawir Sjadzali, Islam dan Tata Negara: Ajaran, Sejarah dan Pemikiran, h. 68

${ }^{23}$ Gagasan Locke tentang kontrak sosial dapat dilihat dalam bukunya, Two Treatises of the Government. Berbeda dengan Hobbes, menurutnya, raja adalah pihak atau partner dari kontrak sosial itu dan kontrak itu antara raja di satu pihak dan rakyat di lain pihak seperti halnya kontrak kedua menurut Brutus dan mirip dengan teori kontrak Mawardi. Konsekwensi adanya kontrak ini menurut locke, pemerintahan itu merupakan suatu trust (amanah) sedangkan rakyat sebagai trustor dan sekaligus beneficiary (pemberi amanah dan sekaligus kepentingannya sebagai yang diamanahkan) dan raja sebagai trustee (penerima amanat). H. Munawir Sjadzali, Islam dan Tata Negara: Ajaran, Sejarah dan Pemikiran, h. 68

${ }^{24}$ Pandangan Rousseau sependapat dengan al-Mawardi, Hobbes dan Locke bahwa hanya ada satu kontrak, namun ada beberapa hal yang berbeda dalam pandangan Rousseau, yaitu: 1. Kontrak sosial itu hanya antara sesame rakyat atau anggota-anggota masyarakat. 2. Melalui kontrak sosial itu masing-masing melimpahkan segala hak perorangannya kepada komunitas sebagai satu keutuhan. H. Munawir Sjadzali, Islam dan Tata Negara: Ajaran, Sejarah dan Pemikiran, h. 69.

${ }^{25}$ Farabi hidup pada zaman kekuasaan Abbasiyyah diguncang oleh berbagai gejolak, pertentangan dan pemberontakan. Lahir pada masa pemerintahan khalifah mu'tamid dan meninggal pada masa pemerintahan Khalifah Muti', suatu periode paling kacau dan tidak ada stabilitas politik sama sekali. Pada waktu itu timbul banyak macam tantangan, bahkan pemberontakan terhadap kekuasaan Abbasiyyah dengan berbagai motif: agama, kesukuan, dan kebendaan. H. Munawir Sjadzali, Islam dan Tata Negara: Ajaran, Sejarah dan Pemikiran, h. 50.
${ }^{26}$ Amandemen UUD 1945, Pdf amandemen uud 1945 disdik.kaltimprov.go.id/ read/getfile/3. Diakses Tanggal 16 Juli 2015.

${ }^{27}$ Prinsip ini tidak hanya dapat diterapkan dalam bidang politik kenegaraan tetapi juga dijalankan pada aspek lain yang berkaitan dengan kehidupan manusia baik sosial budaya, hukum, ekonomi dan lain-lain. Kajian konprehensif mengenai prinsip syura' dapat dilihat pada Dr. Taufiq Muhammad asySyawi, Syura; Bukan Demokrasi, terj. Djamaluddin Z. S, Fiqh asy-Syura wa alIstisyarat (cet. 1; Jakarta: Gema Insani Press, 1997).

${ }^{28}$ Dalam pasal 5 undang-undang pilpres menyebutkan persyaratan menjadi calon Presiden dan calon Wakil Presiden adalah: (1) bertakwa kepada Tuhan Yang Maha Esa;(2)Warga Negara Indonesia sejak kelahirannya dan tidak pernah menerima kewarganegaraan lain karena kehendaknya sendiri;(3) tidak pernah mengkhianati negara, serta tidak pernah melakukan tindak pidana korupsi dan tindak pidana berat lainnya; (4)mampu secara rohani dan jasmani untuk melaksanakan tugas dan kewajiban sebagai Presiden dan Wakil Presiden;(5) bertempat tinggal di wilayah Negara Kesatuan Republik Indonesia;(6) telah melaporkan kekayaannya kepada instansi yang berwenang memeriksa laporan kekayaan penyelenggara negara;(7) tidak sedang memiliki tanggungan utang secara perseorangan dan/atau secara badan hukum yang menjadi tanggung jawabnya yang merugikan keuangan negara;(8)tidak sedang dinyatakan pailit berdasarkan putusan

pengadilan;(9) tidak pernah melakukan perbuatan tercela;(10) terdaftar sebagai Pemilih;(11) memiliki Nomor Pokok Wajib Pajak (NPWP) dan telah melaksanakan kewajiban membayar pajak selama 5 (lima) tahun terakhir yang dibuktikan dengan Surat Pemberitahuan Tahunan Pajak Penghasilan Wajib Pajak Orang Pribadi;(12)belum pernah menjabat sebagai Presiden atau Wakil Presiden selama 2 (dua) kali masa jabatan dalam jabatan yang sama; m. setia kepada Pancasila sebagai dasar negara, UndangUndang Dasar Negara Republik Indonesia 
Tahun 1945, dan cita-cita Proklamasi 17 Agustus 1945;(13) tidak pernah dijatuhi pidana penjara berdasarkan putusan pengadilan yang telah mempunyai kekuatan hukum tetap karena melakukan tindak pidana yang diancam dengan pidana penjara 5 (lima) tahun atau lebih;(14) berusia sekurangkurangnya 35 (tiga puluh lima) tahun;(15) berpendidikan paling rendah tamat Sekolah Menengah Atas (SMA), Madrasah Aliyah (MA), Sekolah Menengah Kejuruan (SMK), Madrasah Aliyah Kejuruan (MAK), atau bentuk lain yang sederajat;(16) bukan bekas anggota organisasi terlarang Partai Komunis Indonesia, termasuk organisasi massanya, atau bukan orang yang terlibat langsung dalam G.30.S/PKI; dan (17). memiliki visi, misi, dan program dalam melaksanakan pemerintahan negara Republik Indonesia. UU Pilpres, http://www.rumahpemilu.com/public/doc/2014 10_27_06 42 44_UU_23 tahun_2014.pdf . Diakses Tanggal 15 Juli 2015

${ }^{29}$ Farid Abdul Khaliq, Fikih Politik Islam, terj. Fathurrahman A Hamid, Lc. Fi alFiqh al-Siyasi al-islami Mabadi Dusturiyyah asy-Syura al-adl al-Musawah (Jakarta: Amzah, 2005), h. 79

${ }^{30}$ Imam al-Mawardi, al-Ahkam alSulthaniyyah, h. 6

${ }^{31}$ Amandemen UUD 1945, Pdf amandemen uud 1945 disdik.kaltimprov.go.id/ read/getfile/3. Diakses Tanggal 16 Juli 2015

${ }^{32}$ Amandemen UUD 1945, Pdf amandemen uud 1945 disdik.kaltimprov.go.id/ read/getfile/3. Diakses Tanggal 16 Juli 2015

${ }^{33}$ Mengenai isi perjanjian dalam sumpah tersebut dapat dilihat Pasal 9 ayat 1 Amandemen UUD 1945.

${ }^{34}$ Abdul Muin Salim menyebutkan bahwa lembaga ini hanya berwenang membuat peraturan perundang-undangan yang berkenaan dengan perkara-perkara atau masalah bukan akidah dan ritual dan yang tidak diatur secara tegas dalam al-Quran dan Sunnah; juga peraturan yang berkenaan dengan pelaksanaan hukum Allah. Lihat Dr. Abd. Muin Salim, Fiqh Siyasah; Konsepsi Kekuasaan Politik dalam al-Qur'an (Cet. 2; Jakarta: Rajawali Pers, 1995), h. 303. 